\title{
Macrobius, Saturnalia 3. 9 and the Roman Cult of Iuno Caelestis
}

\author{
Roman A. Isaenko
}

St. Petersburg State University,

7-9, Universitetskaya nab., St. Petersburg, 199034, Russian Federation; isaenkora@mail.ru

For citation: Roman A. Isaenko. Macrobius, Saturnalia 3. 9 and the Roman Cult of Iuno Caelestis. Philologia Classica 2019, 14 (2), 208-215. https://doi.org/10.21638/11701/spbu20.2019.203

The cult of Tanit, the patron goddess of Carthage, known to the Romans as Iuno Caelestis, had long been thought to have been transferred to Rome during the rule of Septimius Severus, as a number of inscriptions and coins mentioning or depicting the deity date back to this period. More recently, an alternative hypothesis was proposed, disputing the importance of this evidence and suggesting that the worship of Iuno Caelestis had been introduced by Elagabalus, along with a Carthaginian statue of the goddess that had been wed to his own divine patron. This article aims to defend the original dating by examining a ritualistic formula preserved by Macrobius, according to which Iuno Caelestis was summoned to Rome by Scipio Aemilianus at the end of the Third Punic War. The article argues that while the formula itself is most likely apocryphal, the information it contains still constitutes an etiological legend of the Roman cult's foundation, and it would not exist if the cult did not. Therefore, the reign of Septimius Severus, the time period when the formula was recorded by Macrobius' own source, Serenus Sammonicus, can be used as a terminus ante quem for the purposes of dating the cult's transfer.

Keywords: Elagabalus, evocatio, Iuno Caelestis, Macrobius, religion, Serenus Sammonicus, Septimius Severus.

Macrobius' account of evocatio, a ritual used by Roman military commanders to convince the patron deity of a besieged city to abandon it in exchange for equal or more opulent worship in Rome, contains the following formula (Macrob. Sat. 3. 9. 7-8):

si deus, si dea est, cui populus civitasque Carthaginiensis est in tutela, teque maxime, ille qui urbis huius populique tutelam recepisti, precor venerorque veniamque a vobis peto ut vos populum civitatemque Carthaginiensem deseratis, loca templa sacra urbemque eorum relinquatis, absque

(C) St. Petersburg State University, 2019 
his abeatis eique populo civitati metum formidinem oblivionem iniciatis, proditique Romam ad me meosque veniatis, nostraque vobis loca templa sacra urbs acceptior probatiorque sit, mihique populoque Romano militibusque meis praepositi sitis ut sciamus intellegamusque. si ita feceritis, voveo vobis templa ludosque facturum.

"I call upon the one in whose protection are the people and community of Carthage, whether it be a god or a goddess, and upon you above all, who have undertaken to protect this city and people, and ask you all for your favor: may you all desert the people and community of Carthage, leave their sacred places, temples, and city, and depart from them, and upon this people and community heap fear, dread, forgetfulness, and come to Rome, to me and my people, with kindly spirit, and may our sacred places, temples, city be more acceptable and approved in your sight, and may you be well disposed to me and the Roman people and my army. If you all should do these things so that we know and understand them, I vow that I will make temples and games for you." (transl. Kaster)

Macrobius notes a tendency to conflate evocatio with a different ritual, devotio (used to dedicate a city that the Romans intended to demolish to the gods of the netherworld), and states that the two rites made use of two different formulas, both of which can be found in the fifth book of Res Reconditae, a lost work written by Serenus Sammonicus who in turn claimed to have discovered them in an unnamed book authored by a man known only by his nomen, Furius (Macrob. Sat. 3. 9. 6):

sed videndum ne quod nonnulli male aestimaverunt nos quoque confundat, opinantes uno carmine et evocari ex urbe aliqua deos et ipsam devotam fieri civitatem. nam repperi in libro quinto Rerum reconditarum Sammonici Sereni utrumque carmen, quod ille se in cuiusdam Furii vetustissimo libro repperisse professus est.

"We should see to it, however, that the mistake some have fallen into not confuse us too - I mean the belief that a single spell both summons the gods from a city and devotes the city to destruction. For I have found both spells in Book 5 of Serenus Sammonicus' Secret History, and he says that he found them in the very ancient book of a certain Furius." (transl. Kaster)

The unanimously accepted implication of the formula, which is written from the point of view of a commander (as its use of the words militibus meis shows) and names Carthage as the ritual's object, is that evocatio was used to bring Iuno Caelestis (i. e. the Phoenician Tanit), the tutelary goddess of the North African city, to Rome by Scipio Aemilianus who oversaw the destruction of Carthage at the end of the Third Punic War in 146 BCE. This opinion is shared by Servius (Serv. In Aen. 12. 841):

Sed constat bello Punico secundo exoratam Iunonem, tertio vero bello a Scipione sacris quibusdam etiam Romam esse translatam.

'It is known that during the Second Punic War Juno was appeased, and that during the third war Scipio brought her to Rome with the use of certain rituals.'

Servius does not name his source, but it is likely that he, too, was familiar with Serenus' Res Reconditae. He quotes the words eique populo civitatique metum formidinem oblivionem iniciatis, differing from Macrobius' version of the formula only in the addition of a -que after civitati, when he examines the folly of the Trojans who bring the wooden horse into the city, despite the clang of weaponry coming from it (Serv. In Aen. 2. 244). 
Additionally, Servius' commentary on the Georgics references Serenus twice, showing his knowledge of the scholar's work (Serv. In G. 1. 30; 1. 102). ${ }^{1}$

However, this implication is not supported by literary accounts of the fall of Carthage. A lengthy description of this event can be found in Appian, who specifically covers the matter of the Romans' religious conduct. First, he mentions the pillaging of a temple of Apollo (App. Pun. 127):

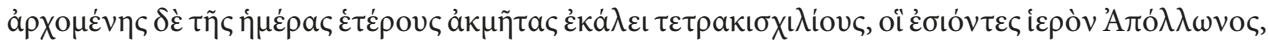

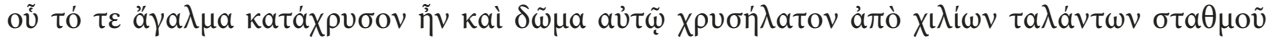

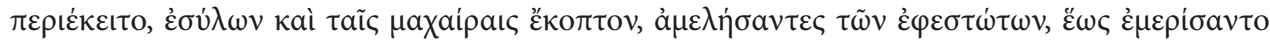

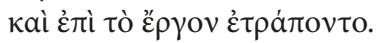

"At daylight he brought in 4000 fresh troops. They entered the temple of Apollo, whose statue was there, covered with gold, in a shrine of beaten gold, weighing 1000 talents, which they plundered, chopping it with their swords and disregarding the commands of their officers until they had divided it among themselves, after which they returned to their duty." (transl. White)

Afterwards, Appian describes the punishment inflicted upon those who participated in this act, Scipio's permission to return the temple offerings that the Carthaginians previously took away from Sicily, and a ritualistic burning of weapons, siege machines, and ships (App. Pun. 133):

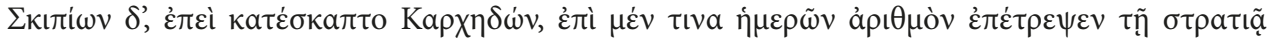

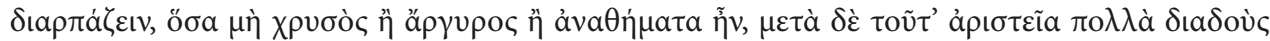

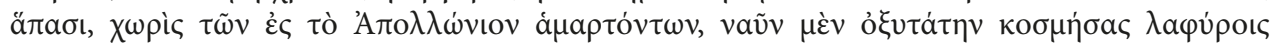

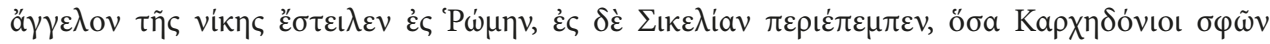

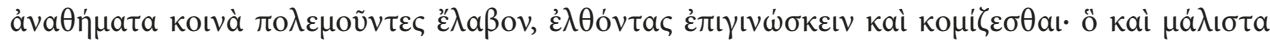

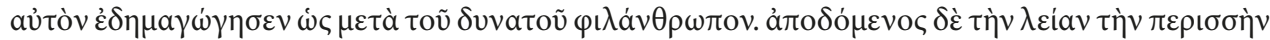

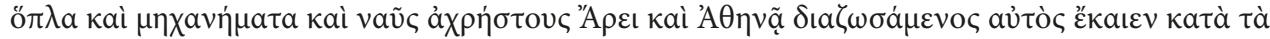
$\pi$ đátpla.

"Carthage being destroyed, Scipio gave the soldiers a certain number of days for plunder, reserving the gold, silver, and temple gifts. He also gave numerous prizes to all who had distinguished themselves for bravery, except those who had violated the shrine of Apollo. He sent a swift ship, embellished with spoils, to Rome to announce the victory. He also sent word to Sicily that whatever temple gifts they could identify as taken from them by the Carthaginians in former wars

1 As for Servius' claim regarding Iuno and the Second Punic War, Vsevolod Basanoff uses it to suggest the existence of a different wartime ritual called exoratio (Basanoff 1947, 36-37), supposedly performed to placate the deities of hostile cities that the Romans did not intend to destroy afterwards (Basanoff 1947, 55). However, this reasoning appears to be based on a misunderstanding of Servius' words. No historical text makes mention of the Romans reaching out to the Carthaginian Iuno during the Second Punic War. On the other hand, Livy describes five instances of various ill omens being reported at or near Italian temples of the goddess (specifically, Iuno Sospita and Iuno Regina): ravens nesting inside, statues bleeding, rains of stone, a thunderbolt striking a temple on the Aventine Hill. In all cases, these sightings are responded to with luxurious countermeasures: golden offerings from the matrons, new statues, animal sacrifices (Livy 21. 62. 4-8; 23. 31. 15; 24. 10. 6-13;27.37. 7-15;29. 14. 3-4). Since Servius does not apply any particular epithet to Iuno as he makes his claim, it seems quite possible that he conflates the Italian and the Carthaginian goddesses, treating them as different aspects of one being, just as Vergil's poem portrays Iuno as a single character, despite its events taking place both in Carthage and in Italy. Furthermore, such conflation was likely responsible for the increase in the sightings of evil portents during the Second Punic War: if the Romans thought that Iuno's favor of the Carthaginian side was evident in Hannibal's successes, they would expect the goddess to be displeased with them and would extend this displeasure to other goddesses known as Iuno. 
they might come and take away. Thus he endeared himself to the people as one who united clemency with power. The rest of the spoils he sold, and, in sacrificial cincture, burned the arms, engines, and useless ships as an offering to Mars and Minerva, according to the Roman custom." (transl. White)

Despite his attention to such matters, Appian makes no mention of the cult of Iuno Caelestis, the patron goddess of the conquered city the Romans fought three wars against, being transferred to Rome.

Historically, scholars, such as Alfred von Domaszewski $(1895,74)$ and Georg Wissowa (1902, 312-313), attributed the time of Iuno Caelestis' arrival in Rome to the rule of Septimius Severus and his sons, Caracalla and Geta, as the earliest evidence of the goddess having a cult recognized by the Roman state can be argued to date back to this period.

The first piece of such evidence was thought to be provided by a verse inscription on a panel discovered in Carvoran, one of the Roman forts positioned along Hadrian's Wall (CIL VII, 759; RIB 1791:):

\author{
imminet leoni Virgo caeles|ti situ \\ spicifera iusti in|ventrix urbium conditrix | \\ ex quis muneribus nosse con|tigit deos: \\ ergo eadem mater divum | Pax Virtus Ceres \\ dea Syria | lance vitam et iura pensitans. \\ in caelo visum Syria sidus edi|dit \\ Libyae colendum: inde | cuncti didicimus. | \\ ita intellexit numine inductus $\mid$ tuo \\ Marcus Caecilius Do|natianus militans \\ tribunus | in praefecto dono principis.
}

"The Virgin in her heavenly place rides upon the Lion; bearer of corn, inventor of law, founder of cities, by whose gifts it is man's good lot to know the gods: therefore she is the Mother of the gods, Peace, Virtue, Ceres, the Syrian Goddess, weighing life and laws in her balance. Syria has sent the constellation seen in the heavens to Libya to be worshipped: thence have we all learned. Thus has understood, led by thy godhead, Marcus Caecilius Donatianus, serving as tribune in the post of prefect by the Emperor's gift." (transl. RIB: https://romaninscriptionsofbritain.org/ inscriptions/1791 [3.11.2019])

Thomas Hodgkin suggests that under the guise of a syncretic goddess the poem portrays empress Julia Domna, Septimius Severus' wife (Hodgkin 1899, 291-292). This point of view found support of von Domaszewski who additionally contends that the inscription is a prayer meant to be spoken in front of a statue that depicted Julia Domna as the goddess (von Domaszewski 1909, 148-149). However, this interpretation was challenged by Ilsemarie Mundle who notes that the poem makes no mention of Julia Domna and no suggestion that the goddess is to be identified with a mortal woman. She convincingly argues that the inscription was composed for entirely personal reasons, as the tribune who authored it does not mention his unit and praises the deity for assisting him in his career, indicating that it was not written by Caecilius in an official capacity, as part of a state cult (Mundle 1961, 229-230).

A dedicatory stone inscription from Mainz, thought to originate from a Roman military camp and reconstructed by Karl Zangemeister (1892, 296-297), appears to explicitly identify Julia Domna with Dea Caelestis (CIL XIII, 6671): 
[Iuliae Augustae] Caelesti deae | [matri imperator]is Caesaris | [M. Aureli Anton]ini Pii Felicis | [Augusti Parth]ici maximi| [Britannici maxi]mi Germanici|[maximi itemqu] senatus patri|[ae et castror] um in honorem | [legionis XXII A]ntoninianae pr(imigeniae)|[p(iae) f(idelis)...] us Quirina $A N|[\ldots] A N A|[\ldots]$

"To Julia Augusta, the Heavenly Goddess, mother to emperor Caesar Marcus Aurelius Antoninus, the Pious, the Fortunate, the August, the Parthian Maximus, the British Maximus, the German Maximus, as well as [mother] to the senate, the country, and the military camps, in the honor of [Fortuna] Primigenia's pious, loyal 22nd Legion... Quirina...”

The significance of this identification was questioned by Mundle as well: she contends that there is no reason to think that such associations were endorsed by the empress, arguing that this inscription likewise reflects its author's personal religious views and not a state-backed belief (Mundle 1961, 231-233).

A large number of coins, minted during the Severan period and bearing an image of Iuno Caelestis, has been discovered and catalogued (RIC IV.I, p. 116, no. 193; p. 125, no. 266-267; p. 194, no. 759-760; p. 195, no. 763-763A, no. 766-766A; p. 231, no. 130 (a, b); p. 232, no. 131 (a, b); p. 279, no. 415 (a, b, c, d); p. 280, no. 418A; p. 289, no. 471). The goddess is depicted riding on the back of a lion and carrying a thunderbolt, a drum, a scepter, or a branch. The words Indulgentia Augg. in Carth. adorn the coins. Once again, Mundle argues (1961, 233-235) that these coins cannot be used to prove the existence of an official cult of Dea Caelestis in Rome, since the goddess appears on them only as a representation of Carthage, and it is likely that they were minted to commemorate the grant of ius Italicum to Carthago, attested in the Digesta (50. 15. 8. 11):

In Africa Carthago, Utica, Leptis magna a divis Severo et Antonino iuris Italici factae sunt.

"In Africa, Carthage, Utica, and Leptis-Magna were granted the privileges of the cities of Italy by the Divine Severus and Antoninus." (transl. Scott)

In Mundle's opinion, it was only during the rule of Elagabalus that an official cult of Iuno Caelestis appeared in Rome (Mundle 1961, 235-237). According to Herodian, Carthago housed an ancient image of Dea Caelestis, connected in legends to the time of the city's founding. Elagabalus ordered to have it transferred to Rome, where it became his divine patron's spouse (Hdn. 5. 6. 3-5):

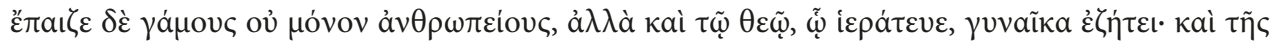

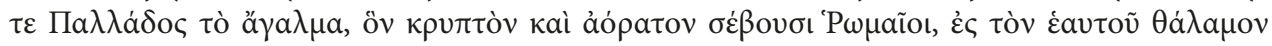

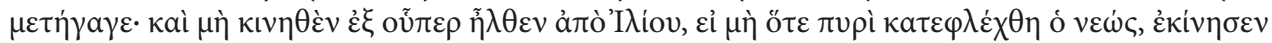

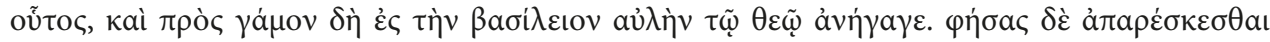

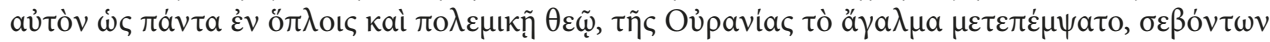

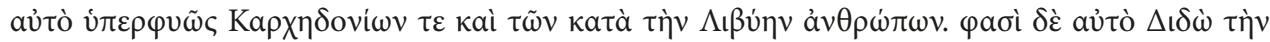

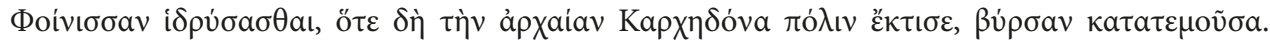

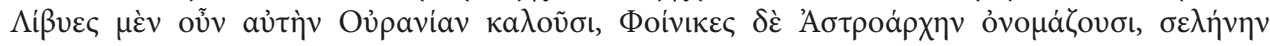

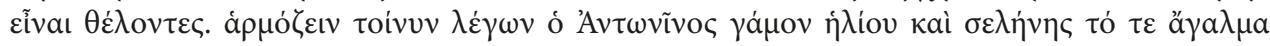

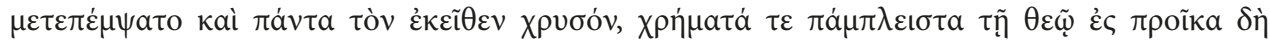

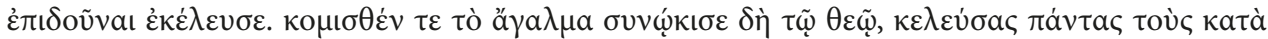

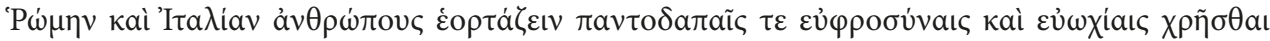

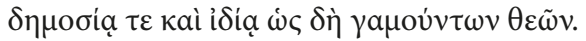




\begin{abstract}
"Not content with making a mockery of human marriage, he even sought a wife for the god whose priest he was. He brought into his own bedroom the statue of Pallas which the Romans worship hidden and unseen. Even though this statue had not been moved from the time when it was first brought from Troy, except when the temple of Vesta was destroyed by fire, Elagabalus moved it now and brought it into the palace to be married to his god. But proclaiming that his god was not pleased by a goddess of war wearing full armor, he sent for the statue of Urania which the Carthaginians and Libyans especially venerate. This statue they say Dido the Phoenician set up at the time when she cut the hide into strips and founded the ancient city of Carthage. The Libyans call this goddess Urania, but the Phoenicians worship her as Astroarche, identifying her with the moon. Claiming that he was arranging a marriage of the sun and the moon, Elagabalus sent for the statue and all the gold in the temple and ordered the Carthaginians to provide, in addition, a huge sum of money for the goddess' dowry. When the statue arrived, he set it up with his god and ordered all men in Rome and throughout Italy to celebrate with lavish feasts and festivals, publicly and privately, in honor of the marriage of the deities." (transl. Echols)
\end{abstract}

A number of later scholars - Francesca Ghedini (1984, 144-145) and Achim Lichtenberger $(2011,104-107)$ among them - agree with Mundle's analysis. While it is difficult to argue against Mundle's conclusion that the inscription CIL VII, 759 does not identify Iuno Caelestis with Julia Domna, fully dismissing the other evidence and attributing the transfer of the goddess' official cult to Elagabalus leaves Macrobius unaccounted for. According to Historia Augusta, Serenus Sammonicus, named by Macrobius as his source, was murdered among supporters of Geta after Caracalla's ascent to power (SHA M. Ant. 4. 3-4):

[h] isdem diebus occisi sunt innumeri, qui fratris eius partibus faverant. occisi etiam liberti, qui Getae administraverant. caedes deinde in omnibus locis. et in balneis factae caedes, occisique nonnulli etiam cenantes, inter quos etiam Sammonicus Serenus, cuius libri plurimi ad doctrinam extant.

"During this same time there were slain men without number, all of whom had favoured the cause of Geta, and even the freedmen were slain who had managed Geta's affairs. Then there was a slaughtering in all manner of places. Even in the public baths there was slaughter, and some too were killed while dining, among them Sammonicus Serenus, many of whose books dealing with learned subjects are still in circulation." (transl. Magie)

Therefore, Serenus' Res Reconditae, which contained a formula supposedly used by Scipio Aemilianus to summon the patron goddess of Carthage to Rome, had been written years before Elagabalus' rule began. While the claim that it was Scipio who brought the worship of the goddess to Rome is difficult to take as historical fact due to the complete lack of evidence in the centuries between the Third Punic War and the rule of Septimius Severus, it does, at the very least, constitute an etiological legend, and if an etiological legend describing the origin of an official Roman cult of Iuno Caelestis existed before the reign of Elagabalus, so did an official Roman cult of Iuno Caelestis.

Macrobius states that Serenus used cuiusdam Furii vetustissimus liber as his own source. However, Wissowa already suspected the formula of being Serenus' own forgery (Wissowa 1907, 1153). Indeed, while Macrobius cites Serenus in an exemplary manner (he names the author's cognomina, the name of the work, and even the specific volume), his description of Furius' mysterious book is much more vague, containing only the author's nomen and an assertion of its respectable age, indicating that he was unable to 
identify the book himself and that what little information he does have to share has to have come from Serenus. This means that Serenus chose to describe his source in a way that would instill the reader with trust (by associating the book with a reputable gens and appealing to the authority of antiquity), but would not help them to find it (by withholding its name and avoiding further description of its contents). Elizabeth Rawson suggests to identify quidam Furius with Lucius Furius Philus, a member of the Scipionic Circle and potentially a pontifex (Rawson 1973, 168-170), but for this identification to be convincing, the assertion that it was Scipio who transferred the cult of Iuno Caelestis to Rome would have to be true, which does not appear to be the case.

Furthermore, it is not only the circumstances of Serenus' death that connect him to Septimius Severus and his sons. Historia Augusta mentions that some of his books were dedicated to Caracalla (SHA Ant. Geta 5. 6):

Sereni Sammonici libros familiarissimos habuit, quos ille ad Antoninum scripsit.

"His favourite books were the works of Serenus Sammonicus, addressed by him to Antoninus." (transl. Magie)

This claim is supported by another quotation from Serenus preserved by Macrobius (Macrob. Sat. 3. 17. 4):

de hac lege Sammonicus Serenus ita refert: Lex Fannia, sanctissimi Augusti, ingenti omnium ordinum consensu pervenit ad populum: neque eam praetores aut tribuni, ut plerasque alias, sed ex omnium bonorum consilio et sententia ipsi consules pertulerunt, cum res publica ex luxuria conviviorum maiora quam credi potest detrimenta pateretur, siquidem eo res redierat, ut gula inlecti plerique ingenui pueri pudicitiam et libertatem suam venditarent, plerique ex plebe Romana vino madidi in comitium venirent, et ebrii de rei publicae salute consulerent.

"About this law Serenus Sammonicus says: The law of Fannius, my most holy eminences, came before the people backed by the huge consensus of all the citizen ranks, and it was not the praetors or tribunes who brought it, as they do most other laws, but the consuls themselves, in accordance with the considered judgment of all good men, since extravagant banqueting was inflicting incredible damage on the commonwealth and matters had reached the point that very many freeborn boys, caught in luxury's snare, were peddling their chastity and freedom and many of the plebs were coming to the comitium completely soused and reaching decisions touching the commonwealth's safety while drunk." (transl. Kaster)

This confirms that Serenus wrote a book addressed to sanctissimi Augusti, in which the history of Roman law was intertwined with moral guidance. Edward Champlin suggests that Serenus could have been a tutor to Caracalla and Geta by arguing that the Serenus Sammonicus mentioned in Historia Augusta as a tutor to Gordian II (SHA Gord. Tres 18. 2) is a fictitious son of the historical Serenus to whom his father's real occupation was assigned (Champlin 1981, 190-191).

Therefore, it is possible to argue that Septimius Severus really was the founder of an official cult of Iuno Caelestis. It is likely that he was concerned that it would prove to be an unpopular measure if an emperor born in the African city of Leptis Magna were to bring the worship of Carthage's patron goddess to Rome (these reservations would be entirely justified, as the reception of Elagabalus' religious reforms showed shortly afterwards). To lower the risk of a public backlash, Septimius Severus could have presented the establish- 
ment of a new cult as a revival of an old one, which had supposedly been brought to Rome by Scipio Aemilianus as a trophy earned as part of his victory over Rome's historic enemy, and Serenus Sammonicus, a scholar close to the emperor's family, could have been used to forge evidence supporting the new cult's false history. This hypothesis allows to explain why the earliest evidence of a state cult of Dea Caelestis and a formula implying that her official worship was centuries older can both be traced back to the same time, the time of Septimius Severus' rule.

\section{References}

Basanoff V. Evocatio. Étude d'un rituel militaire romain. Paris, Presses universitaires de France, 1947.

Champlin E. Serenus Sammonicus. Harvard Studies in Classical Philology 1981, 85, 189-212.

Domaszewski A. von. Abhandlungen zur römischen Religion. Leipzig - Berlin, B. G. Teubner, 1909.

Domaszewski A. von. Die Religion des römischen Heeres. Trier, Fr. Lintz'sche Buchhandlung, 1895.

Echols E. C. (transl.) Herodian of Antioch's History of the Roman Empire from the Death of Marcus Aurelius to the Ascension of Gordian III. Berkeley — Los Angeles, University of California Press, 1961.

Ghedini F. Giulia Domna tra oriente e occidente. Le fonti archeologiche. Roma, L'Erma di Bretschneider, 1984.

Hodgkin T. The Caervoran Inscription in Praise of the Syrian Goddess. Archaeologia Aeliana 1899, 21, 289-292.

Kaster R.A. (ed., transl.) Macrobius. Saturnalia, Vol.II: Books 3-5. Cambridge, MA, Harvard University Press, 2011.

Lichtenberger A. Severus Pius Augustus. Studien zur sakralen Repräsentation und Rezeption der Herrschaft des Septimius Severus und seiner Familie (193-211 n. Chr.). Leiden - Boston, Brill, 2011.

Magie D (transl.). Historia Augusta, Vol.II. Cambridge, MA, Harvard University Press, 1993.

Mundle I. Dea Caelestis in der Religionspolitik des Septimius Severus und der Julia Domna. Historia: Zeitschrift für Alte Geschichte 1961, 10 (2), 228-237.

Rawson E. Scipio, Laelius, Furius, and the Ancestral Religion. The Journal of Roman Studies 1973, 63, 161174.

Scott S. P. The Civil Law, Vol. XI. Cincinnati, Central Trust Company, 1932.

White H. (transl.) Appian's Roman History, Vol. I. London, William Heinemann, 1912.

Wissowa G. Evocatio (deorum), in: RE 1907, VI/1, 1152-1153.

Wissowa G. Religion und Kultus der Römer. München, C. H. Beck, 1902.

Zangemeister K. Rheinische Corpusstudien. Westdeutsche Zeitschrift für Geschichte und Kunst 1892, 11, 267-311.

Received: September 2, 2019

Accepted: October 25, 2019 